\title{
Predictors of tuberculosis infection among adults visiting anti-retroviral treatment center at east and west Gojjam, northwest, Ethiopia, 2017
}

Habtamu Belew ${ }^{1 *}$, Moges Wubie², Getaye Tizazu², Abebaw Bitew and Tesfa Birlew²

\begin{abstract}
Background: Tuberculosis is a serious health risk, for people living with human immune deficiency virus worldwide, and the burden of TB/HIV infection is still high in Ethiopia in particular. Therefore, the aim of this study was to determine the predictors of tuberculosis infection among adults visiting anti-retroviral treatment center in East and West Gojjam, northwest, Ethiopia.

Methods: Institution based unmatched case-control study was employed to determine the predictors of tuberculosis infection among adults visiting anti-retroviral treatment center in east and west Gojjam, Northwest, Ethiopia from March 7-April 15, 2017. Just about 552 participants were participated in the study (139 Cases and 413 controls). Cases were confirmed with active TB and infected with HIV, and controls were HIV positive adults with non-TB. All cases in each health facility who confirmed by acid-fast bacilli, culture and gene expert were considered as TB positive. However, controls were selected by using simple random sampling technique through the above diagnostic criteria and the data were collected with Face to face interview as well as patient medical record were utilized, and the quality of the data were assured, checked, coded, cleaned and entered in EPI-Data version 3.1 and exported to SPSS version 20 for the analysis.
\end{abstract}

Result: Of the total sample (556), just about 552(99.2\%) were participated in the study. 47.5\% were females and 58.9\% were rural dweller. Behavioral and modifiable biological risk factors: alcohol users (AOR $=2.33 ; 95 \% \mathrm{Cl}: 1.34$, 4.07), $\mathrm{BMl}<18.5 \mathrm{~kg} /{ }^{\mathrm{m} 2}$ (AOR =3.03;95\%Cl:1.79,5.14), CD4 count $\leq 200$ cells $/ \mu \mathrm{l}(\mathrm{AOR}=2.34 ; 95 \% \mathrm{Cl}: 1.89,2.79)$ and between 201 and 499 cells/ $\mu \mathrm{l}(\mathrm{AOR}=2.63 ; 95 \% \mathrm{Cl}: 1.01,6.84)$, bedridden and ambulatory $(\mathrm{AOR}=3.3 ; 95 \% \mathrm{Cl}: 1.70,6.29$ and $A O R=8.2 ; 95 \% C l: 4.34,15.64)$, respectively. $T B$ history in the family $(A O R=3.00 ; 95 \% C l: 1.57,5.74)$ were predictors for TB infection. Taking CPT (AOR $=0.36 ; 95 \% \mathrm{Cl}: 0.21,0.62)$ and having early WHO clinical stage I or II (AOR =0.34; 95\%Cl: 0.20, 0.56) had protective effect against TB infection.

Conclusion: From this study, it has been concluded that alcohol users, BMI $<18.5 \mathrm{~kg} / \mathrm{m}^{2}$, CD4 count $<499$ cells $/ \mu \mathrm{l}$, bedridden and ambulatory and TB history were predictors for TB-HIV co-infected adults. Strengthen screening more frequently, CPT Prophlaxysis and treated promptly important to reduce TB co-morbidity.

Keywords: Predictors, Tuberculosis, HIV infection, Anti-retroviral treatment

\footnotetext{
*Correspondence: habtamu1570@gmail.com

'Department of Medical Laboratory Science, College of Medicine and Health

Sciences, Debre Markos University, 269, Debre Markos, Ethiopia

Full list of author information is available at the end of the article
}

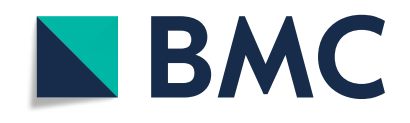

(c) The Author(s). 2020 Open Access This article is licensed under a Creative Commons Attribution 4.0 International License, which permits use, sharing, adaptation, distribution and reproduction in any medium or format, as long as you give appropriate credit to the original author(s) and the source, provide a link to the Creative Commons licence, and indicate if changes were made. The images or other third party material in this article are included in the article's Creative Commons licence, unless indicated otherwise in a credit line to the material. If material is not included in the article's Creative Commons licence and your intended use is not permitted by statutory regulation or exceeds the permitted use, you will need to obtain permission directly from the copyright holder. To view a copy of this licence, visit http://creativecommons.org/licenses/by/4.0/ The Creative Commons Public Domain Dedication waiver (http://creativecommons.org/publicdomain/zero/1.0/) applies to the data made available in this article, unless otherwise stated in a credit line to the data. 


\section{Background}

Tuberculosis (TB) is often the commonest infection to develop among people living with human immunodeficiency virus (PLWHIV). Among the world's 22 highburden tuberculosis countries, Ethiopia ranks the seventh in worldwide and third in Africa [1]. HIV pandemic presents a massive challenge to the control of $\mathrm{TB}$ at all levels. In high HIV prevalence population, TB is a principal cause of morbidity and death, and HIV is driving the tuberculosis epidemic in many countries, especially in sub-Saharan Africa [2]. TB is leading cause of death among PLWHIV, which known as "fatal duo" as HIV reduces the body's defense system and makes them more horizontal to TB infection. On the other hand, TB increases the development of HIV to acquired immune deficiency syndrome (AIDS) stages [3]. The association between HIV and TB often described as a co-epidemic; they are far harsher together than either disease alone in developing countries many people infected with HIV catch TB as the first sign of AIDS [4]. TB is the most common opportunistic infection in PLWHIV worldwide [5]. It is the first presenting sign in the majority of AIDS patients, including those who are taking antiretroviral treatment (ART). Despite major reductions with ART, however, risk of TB remains high in Africa [6, 7]. Globally, an estimated $13 \%$ of TB cases co-infected with HIV, and the bacteria accelerate the progression of HIV to AIDS [7]. Without proper treatment, 90\% of PLWHIV die within months of contracting TB. The current challenge is to find ways of preventing both TB and HIV, and to improve diagnosis and management of co-infection, so the HIV/AIDS and Mycobacterium tuberculosis co-infection is one of the major global challenges in the prevention of $\mathrm{TB}$ and accounts for $33 \%$ HIV related deaths [6, 8]. Progress against HIV has far outstripped global efforts to tackle TB. In 2014, for the first time in decades, TB killed more people than any other infectious disease in the world. HIV infection is the strongest known risk factor for $\mathrm{TB}$ and estimated that there were 1.4 million TB deaths in 2015, and an additional 0.4 million co-morbid deaths [8-10]. HIVinfected people have an annual risk of $5-15 \%$ of developing active TB once infected, and have a much higher risk of developing active TB than HIV-negative individuals [10-13]. In resource-limited settings, the healthcare systems flurry under by the preventive, therapeutic and diagnostic challenges of the HIV-TB syndemic. However, HIV is not the only determinant for developing TB, various other factors: socio-demographic, clinical, life style and environmental are determinant for TB in HIV positives $[14,15]$. In Ethiopia, the ministry of health attempt to improve community level access to care by decentralizing TB/HIV service from hospital to health centers and build up referral systems as well as step up standard operating procedures and standards of care to improve the quality $[16,17]$, but the burden of TB/HIV infection is still high. This unexpected scale of the outbreak of HIV related tuberculosis demands intensive and urgent action, but also there is no such study in the study area conducted before. Therefore, the aim of this study is to identify predictors of tuberculosis infection among HIV infected adults' visiting anti-retroviral treatment center in public health institutions in East and West Gojjam Zone, Northwest Ethiopia, 2017.

\section{Methods}

\section{Study area and period}

The study conducted in the public health institutions in East Gojjam (Debre Markos Referral Hospital, Debre Markos health center, Dejene health center, Bichena health center, Lummame health center \& Yebokela health center). From West Gojjam, Finotselam hospital was included. The study area was selected according to available number of TB/HIV co-infection in the area and computerized documentation system in the health facilities. The study was conducted from March 7 to April 15, 2017 in Northwest, Ethiopia.

\section{Study design}

Institutional based unmatched case-control study design was conducted.

\section{Source population}

All adult HIV infected adults recorded on ART from public health institutions.

\section{Sampling population}

The cases were both active TB and HIV infected adults with TB treatment during the data collection period and registered on TB clinic. Controls were only HIV infected adults and negative for TB and registered on ART.

\section{Eligibility criteria Inclusion criteria}

All adult living with HIV and TB/HIV co-infected individuals with pulmonary tuberculosis, extra Pulmonary tuberculosis and being $\geq 15$ years old and having record on ART and TB clinic in public health institutions in east and west Gojjam were included in the study.

\section{Exclusion criteria}

Those patients, who were seriously ill, had a mental problem and with suspected but unconfirmed TB exclude from this study.

\section{Sample size determination}

As the investigation was unmatched case-control study, the sample size would require for using two-population 
proportion formula to achieve statistically significance results. Therefore, a sample was calculated by taking into account the major exposure variables, and using epi-info version 7 . Among the exposure variables $\mathrm{CD}_{4}$ count, isoniazed preventive therapy (IPT) and cotrimoxazole preventive therapy $(\mathrm{CPT})$ were evaluated. The variables that were given the largest sample size in this case was $\mathrm{CD}_{4}$ count selected as the main exposure variables which given the most favorable sample size, and the study were planned to have $80 \%$ statistical power with a level of significance at $5 \%$ (two-sided) for a case to control ratio of 1:3. Assuming the proportion of low $\mathrm{CD}_{4}$ cell count is $5.6 \%$ for the controls and $13.9 \%$ for the cases [14] and allowing $5 \%$ of non- response rate the resulted sample size were 576.

\section{Sampling procedure}

Regarding to cases a base line data was obtained from the governmental hospitals and public health centers. Two hospitals and five health centers in east and west Gojjam were found to be eligible by simple random sampling.

The principal investigator extracts the required data from the ART and TB registries for the identification of cases and controls. All TB-HIV co-infected adults attending HIV care clinics that could diagnose by direct microscopy, culture, Gene expert and fine needle aspiration and confirmed for TB positive. TB-HIV coinfected adults, who would receive TB treatment and fulfill inclusion criteria at the time of data collection, were included as a case in the study. However, controls were adequate to be sampled and confirmed tuberculosis negative according to the guideline diagnosed; lists of controls were prepared using unique identification numbers from records found in ART clinics and selected by simple random sampling technique by using computergenerated random numbers. Medical registration number used to select controls that fulfill inclusion criteria after giving unique identification numbers in increasing order.

\section{Study variables}

\section{Dependent variable}

Status of tuberculosis among HIV infected adults.

\section{Independent variables}

A Socio demographic characteristic includes (sex, age, marital status, residence, level of education, type of occupation and monthly income). Environmental factors (separate kitchen, Family size, number of windows in the house, the types of floor in the house), Host or behavioral related factors (chewing khat, cigarette smoking, drinking alcohol, history of TB in the past, history of asthma, history of TB in the family, \& history of diabetic mellitus). Clinical variables (WHO clinical stage, hemoglobin level, IPT prophylaxis, CPT prophylaxis, level of $\mathrm{CD}_{4}$ count, functional status of the patient and level of $\mathrm{BMI}$ ) were included.

\section{Operational definitions}

Substance abuse (chewing khat, alcohol consumption and smoking) defined as an individual who is currently using the substance or has a history of regular substance abuse

Active tuberculosis is Mycobacterium tuberculosis disease which is in active state in any part of the body as determined by either, a smear microscopy, culture or molecular taken from any source in the person's body tests positive for tuberculosis and the person has not completed the appropriate prescribed course of medication for active tuberculosis during the study.

Smear positive pulmonary tuberculosis $\left(\mathrm{PTB}^{+}\right)$diagnosed if single sputum smear examination positive for Acid Fast Bacilli (AFB) by direct microscopy, culture, Gene expert and laboratory confirmation of HIV infection. Extra-pulmonary tuberculosis diagnosed if one specimen from an extra-pulmonary site culture-positive for Mycobacterium tuberculosis or smear positive for AFB or histological or strong clinical evidence consistent with active extra-pulmonary tuberculosis and laboratory confirmation of HIV infection or strong clinical evidence of HIV infection and decision by a clinician to treat with a full course of anti -tuberculosis chemotherapy [14].

\section{Data collection instruments}

To determine the predictors of tuberculosis among HIV infected adults, semi-structured questionnaires were used to collect data in study participants from selected public health institutions in East and West Gojjam Zone from primary and secondary sources. The data were collected by face-to-face interview of patients and extracted from ART card and logbooks. Five trained clinical diploma nurses who were not in charge of an HIV and TB care clinic conducted the interview with study participants using questionnaires.

\section{Data quality control}

Before data collection period, data collectors trained about the objective of the research. The principal investigators were given the training about the objective of the study and data collection system by using semistructured questionnaires in a one-day period. The questionnaires would prepare in English, translated into Amharic and back translated into English to check consistency. Pre-test carried out on 16 PLWHIV positive adults in Amanual health center in Machakele woreda to familiarize the interviewer with the instrument and to check the coherence. To keep the quality of data, 
principal investigator was checking the questionnaires for its completeness in each day.

\section{Data processing and analysis}

The data were checked for completeness and consistencies, and cleaned, coded and entered using Epi-Data V.3.1computer program and exported to statistical package for social science (SPSS) version 20 for analysis. The whole data were cleaned to minimize data entry errors and observed the unities of the data. Inconsistencies were verified using cross tabulation. Descriptive frequency statistics were run to see the general distribution of the data. Frequencies and proportions used to describe the study subjects in relation to the study variables. Multiple logistic regressions were used to review the predictors of TB in HIV infected adults as the most important statistical method of analysis by using backward logistic regression variable selection technique. All explanatory variables that were associated with the outcome variable in bivariate analysis with $p$-value of $<0.25$ [36] were candidate in the initial logistic regression models of multivariate analysis. The crude and adjusted odds ratios together with their corresponding $95 \%$ confidence intervals were computed. A $P$-value $<0.05$ considered as statistically significant with the outcome variable.

\section{Results}

Among 556 selected study participants, 552 study subjects $(139$ cases $(25.2 \%)$ and 413 controls (72\%) were responded and the overall response rate were 99.2\% (96.5\% for cases and $99 \%$ for controls). A higher percentage of women observed in the study participants 301(54.5\%). Sixty-six (47.5\%) of the cases and 235 (57\%) of the controls were females. The median age of the participants was 32.5 years and IQR of 25-41.75. Seventysix $(54.7 \%)$ of the cases and $249(60.3 \%)$ of the controls were rural residents. More than $2 / 3$ of the study participants were completed primary school and above; $66.9 \%$ in the cases and $71.67 \%$ in the controls (Table 1).

\section{Distribution of behavioral and environmental factors for TB among HIV infected adults}

Thirty one $(22.3 \%)$ of the cases and $48(11.6 \%)$ of the controls were chewing chat. Among the environmental variables $87(62.6 \%)$ of the cases and $300(72.6 \%)$ of the controls were lived in mud/soil types of floor in the house (Table 2).

Clinical factors for TB infection among HIV positive adults The median CD4 count of the study participants were 393.5 cells $/ \mu \mathrm{l}$ and IQR of 210.5-624.00. Sixty-two (44.6\%) of the cases and 103 (39.5\%) of the controls had $\mathrm{CD}_{4}$ cell counts $\leq 200$ cells/ $\mu \mathrm{l}$. One hundred three $(74 \%)$
Table 1 Descriptive statistics of socio demographic characteristics for factors of TB infection among HIV positive adults at east and west Gojjam, Northwest, Ethiopia, 2017

\begin{tabular}{|c|c|c|}
\hline Variables & $\begin{array}{l}\text { Cases n (\%) } \\
\boldsymbol{n}=139\end{array}$ & $\begin{array}{l}\text { Controls n (\%) } \\
\boldsymbol{n}=413\end{array}$ \\
\hline \multicolumn{3}{|l|}{ Sex } \\
\hline Male & $73(52.5)$ & $178(43)$ \\
\hline Female & $66(47.5)$ & $235(57)$ \\
\hline \multicolumn{3}{|l|}{ Age } \\
\hline $15-34$ years & $72(51.8)$ & $224(54.2)$ \\
\hline$\geq 35$ years & $67(48.2)$ & 189(45.8) \\
\hline \multicolumn{3}{|l|}{ Residence } \\
\hline Urban & $63(45.3)$ & 164(39.7) \\
\hline Rural & $76(54.7)$ & $249(60.3)$ \\
\hline \multicolumn{3}{|l|}{ Marital status } \\
\hline Single & $28(20.14)$ & $68(16.5)$ \\
\hline Married & $52(37.41)$ & $219(53)$ \\
\hline Divorced & $32(23.02)$ & 75(18.2) \\
\hline Widowed & $27(19.43)$ & $51(12.3)$ \\
\hline \multicolumn{3}{|l|}{ Level of education } \\
\hline No education & $46(33.1)$ & 117(28.33) \\
\hline Primary & $48(34.5)$ & $112(27.12)$ \\
\hline Secondary & $26(18.7)$ & $100(24.21)$ \\
\hline Above 12 & 19(13.7) & $84(20.34)$ \\
\hline \multicolumn{3}{|l|}{ Occupation } \\
\hline Employed & $18(12.95)$ & 56(13.6) \\
\hline Unemployed & $17(12.23)$ & $52(12.6)$ \\
\hline Others & 104(74.82) & $305(73.8)$ \\
\hline \multicolumn{3}{|l|}{ Monthly income } \\
\hline$<650$ Birr & $62(44.6)$ & $122(29.5)$ \\
\hline$\geq 650$ Birr & $77(55.4)$ & $291(70.5)$ \\
\hline
\end{tabular}

Others indicate merchant, farmer, and student

of the cases and 125 (30.3\%) of the controls had BMI of less than $18.5 \mathrm{~m}^{2} / \mathrm{kg}$ (Table 3 ).

Bivariate analysis for factors associated with TB infection among HIV positive adults in east and west Gojjam zone The odds of TB infection among HIV infected adults were 2.83 times higher in previously TB history in the family as compared to non-TB history. $\mathrm{CD}_{4}$ count $\leq 200$ cells $/ \mu$ and 201-499cells/ $\mu$ l (crude OR (COR) 2.55;95\%CI 1.615,4.016 and $12.01 ; 95 \%$ CI $6.388,22.588$ ) times more likely exposed for TB infection among HIV positive adults as compared to $\mathrm{CD}_{4}$ count of $\geq 500$ cells $/ \mu$ l (Table 4 ).

Multivariate analysis for the predictors of TB infection among HIV infected adults in east and west Gojjam Thirteen variables that indicated $P$-value $\leq 0.25$ in the binary logistic regressions were marital status, monthly 
Table 2 Distribution of behavioral and environmental factors for TB infection among HIV-infected adults at east and west Gojjam, Northwest, Ethiopia, 2017

\begin{tabular}{|c|c|c|}
\hline Variables & $\begin{array}{l}\text { Cases n (\%) } \\
\boldsymbol{N}=139\end{array}$ & $\begin{array}{l}\text { Controls n (\%) } \\
\boldsymbol{N}=413\end{array}$ \\
\hline \multicolumn{3}{|c|}{ Khat chewing } \\
\hline Yes & $31(22.3)$ & $48(11.6)$ \\
\hline No & 108(77.7) & $365(88.4)$ \\
\hline \multicolumn{3}{|l|}{ Smoking } \\
\hline Yes & 16(11.5) & $31(7.5)$ \\
\hline No & 123(88.5) & $382(92.5)$ \\
\hline \multicolumn{3}{|c|}{ Drinking alcohol } \\
\hline Yes & 49(35.3) & $71(17.2)$ \\
\hline No & $90(64.7)$ & $342(82.8)$ \\
\hline \multicolumn{3}{|c|}{ TB in the past } \\
\hline Yes & $17(12.2)$ & $58(14)$ \\
\hline No & 122(87.8) & $355(86)$ \\
\hline \multicolumn{3}{|l|}{ Asthma } \\
\hline Yes & $24(17.3)$ & $40(9.7)$ \\
\hline No & 115(82.7) & $373(90.3)$ \\
\hline \multicolumn{3}{|c|}{ Diabetic mellitus } \\
\hline Yes & $30(21.6)$ & $60(14.5)$ \\
\hline No & 109(78.4) & $353(85.5)$ \\
\hline \multicolumn{3}{|c|}{ TB in the family } \\
\hline Yes & $33(23.7)$ & $41(9.9)$ \\
\hline No & 106(76.3) & $372(90.1)$ \\
\hline \multicolumn{3}{|c|}{ Types of floor } \\
\hline Mud/soil & $87(62.6)$ & $300(72.6)$ \\
\hline Cement & $52(37.4)$ & $113(27.4)$ \\
\hline \multicolumn{3}{|l|}{ Family size } \\
\hline$\leq 2$ & $41(29.5)$ & $106(25.7)$ \\
\hline $3-4$ & $65(46.8)$ & $201(48.7)$ \\
\hline$\geq 5$ & $33(23.7)$ & $106(25.6)$ \\
\hline \multicolumn{3}{|c|}{ Separate kitchen } \\
\hline Yes & $91(65.5)$ & $267(64.6)$ \\
\hline No & $48(34.5)$ & 146(35.4) \\
\hline \multicolumn{3}{|c|}{ No of window in the house } \\
\hline 0 & $24(17.3)$ & $61(14.8)$ \\
\hline 1 & $57(41)$ & $126(30.5)$ \\
\hline$\geq 2$ & $58(41.7)$ & $226(54.7)$ \\
\hline
\end{tabular}

income, chewing chat, drinking alcohol, asthma, TB history in the family, $\mathrm{CD}_{4}$ cell count, Hgb level, BMI, functional status of the respondent, CPT prophlaxysis, WHO clinical stage and types of floor in the house were candidate for multivariate analysis. By using backward variable selection methods, a multivariate logistic regression model showed that seven variables
Table 3 Clinical factors for TB infection among HIV positive adults at east and west Gojjam, northwest, Ethiopia, 2017

\begin{tabular}{|c|c|c|}
\hline Variables & $\begin{array}{l}\text { Cases } n(\%) \\
N=139\end{array}$ & $\begin{array}{l}\text { Controls } n(\%) \\
N=413\end{array}$ \\
\hline \multicolumn{3}{|l|}{ CD4 count } \\
\hline$\leq 200 \mathrm{cells} / \mu \mathrm{l}$ & $62(44.6)$ & $64(15.5)$ \\
\hline 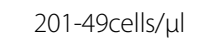 & $62(44.6)$ & 163(39.5) \\
\hline$\geq 500 \mathrm{cells} / \mu \mathrm{l}$ & 15(10.8) & $186(45)$ \\
\hline \multicolumn{3}{|l|}{ Hemoglobin } \\
\hline$<10 \mathrm{mg} / \mathrm{dl}$ & $70(50.4)$ & $80(19.4)$ \\
\hline $10-11.99 \mathrm{mg} / \mathrm{dl}$ & $40(28.8)$ & $99(24)$ \\
\hline$\geq 12 \mathrm{mg} / \mathrm{dl}$ & $29(20.8)$ & 234(56.6) \\
\hline \multicolumn{3}{|l|}{ BMI } \\
\hline$<18.5 \mathrm{~m} 2 / \mathrm{kg}$ & $103(74)$ & 125(30.3) \\
\hline$\geq 18.5 \mathrm{~m} 2 / \mathrm{kg}$ & $36(26)$ & 288(69.7) \\
\hline \multicolumn{3}{|l|}{ Functional Status } \\
\hline Bedridden & 71(51.1) & $36(8.7)$ \\
\hline Ambulatory & $33(23.7)$ & $92(22.3)$ \\
\hline Working & $35(25.2)$ & 285(69) \\
\hline \multicolumn{3}{|l|}{ CPT prophlaxysis } \\
\hline Yes & $82(60)$ & $328(79.4)$ \\
\hline No & $57((40)$ & 85(20.6) \\
\hline \multicolumn{3}{|l|}{ IPT prophylaxis } \\
\hline Yes & $42(30.2)$ & 148(35.8) \\
\hline No & $97(69.8)$ & $265(64.2)$ \\
\hline \multicolumn{3}{|l|}{ WHO Staging } \\
\hline Stage I/II & $38(27.3)$ & $273(66.1)$ \\
\hline Stage III/IV & $101(72.7)$ & $140(33.9)$ \\
\hline
\end{tabular}

were predictors for TB infection among HIV infected adults. From these factors, being patients who drink alcohol $(\mathrm{AOR}=2.33$; 95\%CI: $1.34,4.07)$ was independent predictor of increased TB infection as compared to patients that did not drink alcohol. However, WHO clinical stage I or II $(\mathrm{AOR}=0.34 ; 95 \% \mathrm{CI}$ : 0.20 , $0.56)$ and cotrimoxazole preventive therapy $(\mathrm{AOR}=$ 0.36; 95\%CI: 0.21,0.62) had protective effect against tuberculosis infection. But, monthly income, chat chewing, hemoglobin level, asthma and types of floor in the house were lost their statistical significance in multivariate analysis (Table 5).

\section{Discussion}

This study showed that HIV infected adults taking CPT and early WHO clinical stage I/ II were less likely to the incidence of TB infection. Although, drinking alcohol, TB history in the family, $\mathrm{CD}_{4}$ cell count of $\leq 200 \mathrm{cells} / \mu \mathrm{l}$ and between 201 and 499 cells/ $\mu \mathrm{l}$, functional status of bedridden and ambulatory and having BMI of $<18.5 \mathrm{~kg} /{ }^{\mathrm{m} 2}$ were 
Table 4 Bivariate logistic regression for socio-behavioral, environmental and clinical factors associated with TB infection among HIV positive adults at east and west Gojjam, Northwest, Ethiopia 2017

\begin{tabular}{|c|c|c|c|c|}
\hline Variables & $\begin{array}{l}\text { Cases } n(\%) \\
n=139\end{array}$ & $\begin{array}{l}\text { Controls n (\%) } \\
n=413\end{array}$ & COR(95\%Cl) & $P$-value \\
\hline \multicolumn{5}{|l|}{ Sex } \\
\hline Male & $73(52.5)$ & $178(43)$ & $1.46(0.99,2.147)$ & 0.054 \\
\hline Female & $66(47.5)$ & $235(57)$ & 1 & \\
\hline \multicolumn{5}{|l|}{ Age in years } \\
\hline $15-34$ & $72(51.8)$ & $224(54.2)$ & $.907(0.617,1.332)$ & 0.618 \\
\hline$\geq 35$ & $67(48.2)$ & 189(45.8) & 1 & \\
\hline \multicolumn{5}{|l|}{ Residence } \\
\hline Urban & $63(45.3)$ & $164(40)$ & $1.25(0.854,1.855)$ & 0.245 \\
\hline Rural & $76(54.7)$ & $249(60)$ & 1 & \\
\hline \multicolumn{5}{|l|}{ Marital status } \\
\hline Single & $28(20.14)$ & $68(16.5)$ & $1.7(1.017,2.958)$ & $0.043^{*}$ \\
\hline Married & $52(37.41)$ & 219(53) & $0.96(0.527,1.766)$ & 0.908 \\
\hline Divorced & $32(23.02)$ & $51(18.2)$ & $0.78(0.410,1.477)$ & 0.442 \\
\hline Widowed & $27(19.43)$ & $84(12.3)$ & 1 & \\
\hline \multicolumn{5}{|l|}{ Level Education } \\
\hline No education & $46(33.1)$ & $117(28.3)$ & $0.92(0.567,1.483)$ & 0.725 \\
\hline Primary & $48((34.5)$ & $112(27.1)$ & $1.51(0.872,2.621)$ & 0.141 \\
\hline Secondary & $26(18.7)$ & $100(24.2)$ & $1.74(0.951,3.178)$ & 0.073 \\
\hline Above 12 & $19(13.7)$ & $84(20.4)$ & 1 & \\
\hline \multicolumn{5}{|l|}{ Occupation } \\
\hline Employed & 18(12.95) & $56(13.6)$ & $0.98(0.459,2.108)$ & 0.965 \\
\hline Unemployed & $17(12.23)$ & $52(12.6)$ & $0.95(0.535,1.693)$ & 0.867 \\
\hline Others & 104(74.82) & $305(73.8)$ & 1 & \\
\hline \multicolumn{5}{|l|}{ Monthly income } \\
\hline$<650$ & $62(44.6)$ & $122(29.5)$ & $1.92(1.210,2.853$ & $0.001^{*}$ \\
\hline$\geq 650$ & $77(55.4)$ & $291(70.5)$ & 1 & \\
\hline \multicolumn{5}{|l|}{ Chat chewing } \\
\hline Yes & $31(22.3)$ & $48(11.6)$ & $2.18(1.324,3.599)$ & $0.002^{*}$ \\
\hline No & 108(77.7) & $365(88.4)$ & 1 & \\
\hline \multicolumn{5}{|l|}{ Smoking } \\
\hline Yes & $16(11.5)$ & $31(7.5)$ & $1.6(0.848,3.030)$ & 0.146 \\
\hline No & 123(88.5) & $382(92.5)$ & 1 & \\
\hline \multicolumn{5}{|l|}{ Drinking alcohol } \\
\hline Yes & $49(35.3)$ & $71(17.2)$ & $2.6(1.703,4.039$ & $0.0001^{*}$ \\
\hline No & $90(64.7)$ & $342(82.8)$ & 1 & \\
\hline \multicolumn{5}{|l|}{ TB history past } \\
\hline Yes & $17(12.2)$ & $58(14)$ & $0.85(0.617,1.332)$ & 0.618 \\
\hline No & 122(87.8) & $355(86)$ & 1 & \\
\hline \multicolumn{5}{|l|}{ Asthma } \\
\hline Yes & $24(17.3)$ & $40(9.7)$ & $1.94(1.126,3.365)$ & $0.017^{*}$ \\
\hline No & 115(82.7) & 373(90.3) & 1 & \\
\hline \multicolumn{5}{|l|}{ Diabetic mellitus } \\
\hline Yes & $30(21.6)$ & $60(14.5)$ & $1.62(0.994,2.638)$ & 0.053 \\
\hline
\end{tabular}


Table 4 Bivariate logistic regression for socio-behavioral, environmental and clinical factors associated with TB infection among HIV positive adults at east and west Gojjam, Northwest, Ethiopia 2017 (Continued)

\begin{tabular}{|c|c|c|c|c|}
\hline Variables & $\begin{array}{l}\text { Cases n(\%) } \\
n=139\end{array}$ & $\begin{array}{l}\text { Controls n (\%) } \\
n=413\end{array}$ & $\operatorname{COR}(95 \% \mathrm{Cl})$ & $P$-value \\
\hline No & 109(78.4) & $353(85.5)$ & 1 & \\
\hline \multicolumn{5}{|c|}{ TB history in the family } \\
\hline Yes & $33(23.7)$ & $41(9.9)$ & $2.83(1.702,4.688)$ & $0.0001^{*}$ \\
\hline No & 106(76.3) & $372(90.1)$ & 1 & \\
\hline \multicolumn{5}{|l|}{ CD4 count } \\
\hline$\leq 200 \mathrm{cells} / \mu \mathrm{l}$ & $62(44.6)$ & $64(15.5)$ & $2.55(1.615,4.016)$ & $0.0001^{*}$ \\
\hline 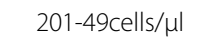 & $62(44.6)$ & $163(39.5)$ & $12(6.388,22.588)$ & $0.0001^{*}$ \\
\hline$\geq 500$ cells $/ \mu \mathrm{l}$ & $15(10.8)$ & $186(45)$ & 1 & \\
\hline \multicolumn{5}{|l|}{ Hemoglobin } \\
\hline$<10 \mathrm{mg} / \mathrm{dl}$ & $70(50.4)$ & 80(19.4) & $2.17(1.33,3.526)$ & $0.002^{*}$ \\
\hline $10-11.99 \mathrm{mg} / \mathrm{dl}$ & $40(28.8)$ & $99(24)$ & $7.06(4.275,11.66)$ & $0.0001^{*}$ \\
\hline$\geq 12 \mathrm{mg} / \mathrm{dl}$ & $29(20.8)$ & $234(56.6)$ & 1 & \\
\hline \multicolumn{5}{|l|}{ BMI } \\
\hline$<18.5 \mathrm{~m} 2 / \mathrm{kg}$ & 103(74) & $125(30.3)$ & $6.59(4.272,10.17)$ & $0.0001^{*}$ \\
\hline$\geq 18.5 \mathrm{~m} 2 / \mathrm{kg}$ & $36(26)$ & $288(69.7)$ & 1 & \\
\hline \multicolumn{5}{|l|}{ Functional Status } \\
\hline Bedridden & $71(51.1)$ & $36(8.7)$ & $5.5(3.126,9.672)$ & $0.0001^{*}$ \\
\hline Ambulatory & $33(23.7)$ & $92(22.3)$ & $16.1(9.425,27.365)$ & $0.0001^{*}$ \\
\hline Working & $35(25.2)$ & 285(69) & 1 & \\
\hline \multicolumn{5}{|l|}{ CPT prophlaxysis } \\
\hline Yes & $82(60)$ & $328(79.4)$ & $0.372(0.247,0.564)$ & $0.0001^{*}$ \\
\hline No & $57((40)$ & 85(20.6) & 1 & \\
\hline \multicolumn{5}{|l|}{ IPT prophlaxyis } \\
\hline Yes & $42(30.2)$ & 148(35.8) & $0.772(0.512,1.173)$ & 0.228 \\
\hline No & $97(69.8)$ & $265(64.2)$ & 1 & \\
\hline \multicolumn{5}{|l|}{ WHO Staging } \\
\hline Stage lorll & $38(27.3)$ & $273(66.10)$ & $0.193(0.126,0.295)$ & $0.0001^{*}$ \\
\hline Stage IIlorIV & $101(72.7)$ & 140(33.9) & 1 & \\
\hline \multicolumn{5}{|l|}{ Type of floor } \\
\hline Mud/soil & $87(62.6)$ & $300(72.6)$ & $0.63(0.420,0.946)$ & $0.026^{*}$ \\
\hline Cement & $52(37.4)$ & $113(27.4)$ & 1 & \\
\hline \multicolumn{5}{|c|}{ No of window In the house } \\
\hline 0 & $24(17.3)$ & $61(14.8)$ & $0.87(0.494,1.533)$ & 0.629 \\
\hline 1 & $57(41)$ & $126(30.5)$ & $1.53(0.881,2.666)$ & 0.130 \\
\hline$\geq 2$ & $58(41.7)$ & $226(54.7)$ & 1 & \\
\hline \multicolumn{5}{|l|}{ Family size } \\
\hline$\leq 2$ & $41(29.5)$ & $106(25.7)$ & $1.20(0.758,1.888)$ & 0.442 \\
\hline $3-4$ & $65(46.8)$ & $201(48.7)$ & $1.24(0.730,2.114)$ & 0.424 \\
\hline$\geq 5$ & $33(23.7)$ & 106(25.6) & 1 & \\
\hline \multicolumn{5}{|l|}{ Separate kitchen } \\
\hline Yes & $91(65.5)$ & $267(64.6)$ & $1.04(0.692,1.552)$ & 0.863 \\
\hline No & $48(34.5)$ & $146(35.4)$ & 1 & \\
\hline
\end{tabular}


Table 5 Predictors of factors associated with TB infection among HIV positive adults visiting ant-retroviral treatment centers at east and west Gojjam, Northwest, Ethiopia, 2017

\begin{tabular}{|c|c|c|c|c|}
\hline Variables & $\begin{array}{l}\text { Cases } \\
N=139\end{array}$ & $\begin{array}{l}\text { Controls } \\
N=413\end{array}$ & $\operatorname{COR}(95 \% \mathrm{Cl})$ & AOR $(95 \% \mathrm{Cl})$ \\
\hline \multicolumn{5}{|l|}{ Drinking alcohol } \\
\hline Yes & $49(35.3)$ & $71(17.2)$ & $2.62(1.70,4.04)$ & $2.33(1.34,4.07)$ \\
\hline No & $90(64.7)$ & $342(82.8)$ & 1 & 1 \\
\hline \multicolumn{5}{|c|}{ TB history in the family } \\
\hline Yes & $33(23.7)$ & $41(9.9)$ & $2.83(1.70,4.69)$ & $3.0(1.57,5.74)$ \\
\hline No & $106(76.3)$ & 372(90.1) & 1 & 1 \\
\hline \multicolumn{5}{|l|}{ WHO staging } \\
\hline Stagel/II & $38(27.3)$ & $273(66.1)$ & $0.19(0.12,0.30)$ & $0.34(0.20,0.56)$ \\
\hline Stage III/IV & $101(72.7)$ & 140(33.9) & 1 & 1 \\
\hline \multicolumn{5}{|l|}{ CPT prophlaxysis } \\
\hline Yes & $82(60)$ & $328(79.4)$ & $0.37(0.25,0.56)$ & $0.36(0.21,0.62)$ \\
\hline No & $57(40)$ & $85(20.6)$ & 1 & 1 \\
\hline \multicolumn{5}{|l|}{ Functional status } \\
\hline Bedridden & $71(51.1)$ & $36(8.7)$ & $5.5(3.13,9.67) 16.1(9.43,27.4)$ & $3.3(1.70,6.29)$ \\
\hline Ambulatory & $33(23.7)$ & $92(22.3)$ & 1 & $8.2(4.34,15.64)$ \\
\hline Working & $35(25.2)$ & $285(69)$ & & 1 \\
\hline \multicolumn{5}{|l|}{ CD4 count } \\
\hline$\leq 200 / \mu l$ & $62(44.6)$ & $64(15.5)$ & $2.55(1.62,4.02)$ & $2.34(1.89,2.79)$ \\
\hline $201-499 \mu \mathrm{l}$ & $62(44.6)$ & 163(39.5) & $12.01(6.39,22.6$ & $2.63(1.01,6.84)$ \\
\hline$\geq 500 \mu \mathrm{l}$ & 15(10.8) & 186(45) & 1 & 1 \\
\hline \multicolumn{5}{|l|}{ BMl } \\
\hline$<18.5 \mathrm{~kg} / \mathrm{m}^{\mathrm{m} 2}$ & 103(74) & $125(30.3)$ & $6.59(4.27,10.17$ & $3.03(1.79,5.14)$ \\
\hline$\geq 18.5 \mathrm{~kg} /{ }^{\mathrm{m} 2}$ & $36(26)$ & 288(69.7) & 1 & 1 \\
\hline
\end{tabular}

AOR Adjusted OR, COR Crude odds ratio, CI Confidence interval, CPT Cotrimoxazole preventive therapy, BMI Body mass index

predictors of expansion of TB infection among HIV infected adults.

Our findings show that alcohol drinkers were predictors of TB infection among HIV positive patients in this study. This was consistent with previous studies conducted in South India [18], West Africa [19] and Amhara Region [20]. Nevertheless, in contrast to the study conducted in Gambia [21] alcohol use is not associated with TB infection, this is because of socio-demography, sampling technique difference and sample size. Smoking was not associated with increased TB infection in this study; this is in agreement with previous study conducted in Addis Ababa [22]. However, in other study conducted in West Africa [19], which identified smoking as predictors for increased TB infection among HIV infected adults, this difference was probably due to sample size difference, social desirability bias where smokers deprived of their smoking status in this study. Previous TB history in the family found to be predictors for increased TB occurrence in the study; this is in line with the study conducted in Croatia, West Africa and southwest Ethiopia [19, 23, 24].

Low body mass index $\left(\mathrm{LBMI}<18.5 \mathrm{~kg} / \mathrm{m}^{2}\right)$ was associated with increased TB infection in this study; this is parallel to a study done in South India [18], Croatia [23], South Africa [25] and south central Ethiopia [26]. This might be due to the fact that under nutrition deteriorates the immunity level that increases the reactivation of latent tuberculosis infection. On the other hand, malnutrition can aggravate the immune deficiency and increase the risk of active TB. Building on the existing knowledge this study also found out that low body mass index increased the likelihood of tuberculosis infection $[22,27]$. The $\mathrm{CD}_{4}$ count $\leq 200$ cells/ $\mu$ l and between 201 and 499 cells/ $\mu$ l were about 2.34 and 2.63 times more likely to develop TB as compared to $\mathrm{CD}_{4}$ count $\geq 500$ cells/ $\mu$ l respectively. This is comparable with previous reports conducted [14, 20, 24, 26, 28-33]. The most important predictors for the development of TB in HIV patients as it frequently reported in literatures are the 
immunological state of the person. Maintaining the CD4 positive cell level as high as possible in patients with advanced disease helps the person to have low risk of reactivation of tubercle bacilli [34]. This study confirm that patients with functional status bedridden and ambulatory were 3.3 and 8 times more likely predictors for the expansion of TB infection, this is related to other findings conducted in Hawassa, Addis Ababa, Northwest Ethiopia and Amhara Region [11, 20, 26, 32, 34]. This is because of the low immunity behavior of the participant during the study period.

In addition, our findings indicating that cotrimoxazole preventive therapy had protective effect against TB infection were also consistent with previous research reports $[11,14,35,36]$. Cotrimoxazole preventive therapy has advantageous effect in increasing CD4 cell count as well falling viral load and CPT is reasonably priced and is generally well tolerated, this endorse TB/HIV associations should give priority high level coverage to the achievement of cotrimoxazole preventive therapy as they have proven usefulness in improving patients condition [27]. Different studies have shown that isonized preventive therapy reduces the risk of infection in people living with HIV however, differently in this study IPT has not associated with risk of $\mathrm{TB}$, because of low coverage of IPT [31] and confounding factors in the study participants. WHO clinical staging and TB infection among HIV positive adults were significantly associated in the study. Those patients in WHO clinical stage I/ II were about 0.340 times less likely to develop TB as compared to those WHO clinical stages III/IV. This is consistent with the study conducted in Amhara Region [20]. Nevertheless, this result was not in line with study done in Tanzania [30] and south central Ethiopia [26]. The possible reason for the difference might be source population, sample size and socio demographic difference. This could make clear when the patients get early WHO stage that the immunity protective capacity will be highest which would make them protect to tuberculosis infection, as well as TB is one of the AIDS defining criteria to categorize the patients into the late WHO clinical staging which again was not addressed with this study. This study indicated determinants of $\mathrm{TB}$ infection among HIV positive adults visiting ant-retroviral treatment centers that would be significant for prioritizing TB screening, diagnosis, treatment and prevention. In addition, the study showed that cotrimoxazole preventive therapy and early WHO clinical stage I or II are protective effect for reducing $\mathrm{TB}$ infection among HIV positive adults in resources-limited settings [32, 33, 37, 38]. The study has the following limitations; case control study design could not set up temporal relationship and can only shows associations; it could not proof causations. Recall bias might have also affected the occurrence of information related to substance use such as cigarette smoking, chat chewing and alcohol consumption; also social desirability bias is unavoidable during data collection period.

\section{Conclusions}

This study indicated that drinking alcohol, previous TB history in the family, functional status being bedridden and ambulatory, $\mathrm{CD}_{4}$ cell count $<500$ cells $/ \mu \mathrm{l}, \mathrm{BMI}<$ $18.5 \mathrm{~kg} /{ }^{\mathrm{m} 2}$ were predictors of increased tuberculosis infection among HIV infected adults visiting ant-retroviral treatment centers in East and West Gojjam Zone and attention is given for these predictors for TB diagnosis. However, this imitated that in early WHO clinical stag I or II and using cotrimoxazole preventive therapy is necessary to reduce the overall risk of TB infection among HIV positive individuals. Hence, these findings supply momentum to strengthen tracing of TB household and member contacts screening.

\section{Abbreviations}

AIDS: Acquired immunodeficiency syndrome; ART: Antiretroviral treatment; AOR: Adjusted odds ratio; $\mathrm{BMI}$ : Body mass index; $\mathrm{CD}_{4}$ : Cluster of deffirnciation of t-lymphocyte cells; CPT : Cotrimoxazole preventive therapy; COR: Crude odds ratio; DMRH: Debre Marko's Referral Hospital; DMU: Debre Marko's University; EPHI: Ethiopian public health institute; FSDH: Finote selam district hospital; HIV: Human immunodeficiency virus; IPT: Isoniazid preventive therapy; $\mathrm{MOH}$ : Ministry of health; PLWHIV: People living with human immunodeficiency virus; SPSS: Statistical package for social science; TB: Tuberculosis; WHO: World Health Organization

\section{Acknowledgements}

We would like to thank Debre Markos University, department of the public health, Health Science College for arranging to conduct the study. I would like to express my deepest gratitude to all staffs of Hospitals and Health centers, specially, in ART and TB clinic, and data collectors and study participants involved in the study.

\section{Authors' contributions}

The authors' responsibilities were as follows: HB design the study, performed the statistical analysis, interpret the result and wrote the manuscript. MW and GT involved in data analysis, interpretation and critically revised the manuscript. $A B$ and $T B$ were supervised the data collection process and approve quality of the data. All authors also highly participated in preparing and revising the final manuscript. The author(s) read and approved the final manuscript.

\section{Funding}

Debre Markos University contributed all financial need for the research.

\section{Availability of data and materials}

The datasets used and/or analysed during the current study are available from the corresponding author on reasonable request. All relevant data are found in the manuscript.

\section{Ethics approval and consent to participate}

Ethical approval was obtained from the institutional review board (IRB) of Debre Markos University, college of medicine and health sciences (Ref. No:-S/ $\mathrm{N} / 206 / 15 / 2017$ ) and approved the procedure of verbal consent. Letter of cooperation was obtained from each health institutions medical director of the hospital and head of the respective health center.

Each study participants were asked by explaining the objective of the study and its significance, and verbal/unsigned informed consent were obtained after clearing up verbal version of a consent form (information sheet) and subjects give their verbal consent in place of written consent to participate. Confidentiality was maintained anonymously and not communicated for other purposes. 


\section{Consent for publication}

Not applicable.

\section{Competing interests}

The authors declare that they have no competing interests.

\section{Author details}

'Department of Medical Laboratory Science, College of Medicine and Health Sciences, Debre Markos University, 269, Debre Markos, Ethiopia. ${ }^{2}$ Department of Public Health, College of Medicine and Health Sciences, Debre Markos University, 269, Debre Markos, Ethiopia.

Received: 8 June 2019 Accepted: 26 July 2020

Published online: 12 August 2020

\section{References}

1. Ethiopian Public Health Institute and Ministry of Health. Report on national TB/HIV sentinel surveillance. Addis Ababa: Ethiopian public health institute; 2015.

2. Federal Ministry of Health Ethiopia. Implementation guideline for TB/HIV collaborative activities. Addis Ababa: Ministry of Health; 2014

3. Kwan CK, Ernst JD. HIV and tuberculosis: a deadly human syndemic. Clin Microbiol Rev. 2011;24(2):351-76.

4. International Federations of Red Cross and Red Crescent Societies. The link between tuberculosis and HIV. https://www.ifrc.org/en/what-we-do/health/ disease/tuberculosis/the-link-between-tuberculosis-and-hiv/. Accessed 20 Dec 2016.

5. Pawlowski A, JM, Sköld M. Tuberculosis and HIV co-infection, current trends, diagnosis and treatment update. PLoS Pathog. 2012;8(2):e1002464.

6. Varghese $G$, Janardhan J, Ralph R, Abrahan O. The twin epidemics of tuberculosis and HIV co-infection. Curr Infect Dis Rep. 2013:15(1):77-84.

7. Getahun H, Gunneberg C, Granich R, Nunn P. HIV infection-associated tuberculosis: the epidemiology and the response. Clin Infect Dis. 2010; 50(Supplement-3):S201-S7.

8. World health organizations: global tuberculosis report, 2015, 20th ed.World Health Organizatioin. https://apps.who.int/iris/handle/10665/191102.

9. Organization W-WH, Organization W-WH. Global tuberculosis report 2016. Geneva: WHO; 2016.

10. World health organizations. the global plan to end TB, 2016-2020.World Health Organization

11. Kibret T, Yalew W, Belianeh G, Asers M. Determinant factors associated with occurrence of tuberculosis among adult people living with HIV after antiretroviral treatment initiation in Addis Ababa, Ethiopia: a case control study. PLoS One. 2013:8(5):e64488.

12. Lonnroth K, Jaramillo E, Williams B, Dye C, Raviglione M. Drivers of tuberculosis epidemics: the role of risk factors and social determinants. Soc Sci Med. 2009;68(12):2240-6.

13. Yim J, Selvaraj P. Genetic susceptibility in tuberculosis. Respirology. 2010; 15(2):241-56.

14. Alemu Y, Awoke W, Wilder-Smith A. Determinants for tuberculosis in HIVinfected adults in Northwest Ethiopia: a multicentre case-control study. BMJ Open. 2016;6(4):e009058.

15. Bucher H, Griffith L, Guyatt G, Sudre P, Naef M. Isoniazid prophylaxis for tuberculosis in HIV infection: a meta-analysis of randomized controlled trials. AIDS. 1999:13:501-7.

16. Dalbo M, Tamiso A. Incidence and predictors of tuberculosis among HIV/ AIDS infected patients: a five-year retrospective follow-up study. Adv Infect Dis. 2016;6:70-81.

17. Mugusi F, Mehta S, Villamor E, Urassa W, Saathoff E, Bosch R, Fawzi W. Factors associated with mortality in HIV-infected and uninfected patients with pulmonary tuberculosis. BMC Public Health. 2009;9:409.

18. Hiregoudar V, Raghavendra B, Karinagannavar A, Karingannavar A, Khan W Kamble S, Goud T. Proportion and determinants of tuberculosis among human immunodeficiency virus-positive patients attending the antiretroviral therapy center attached to a Medical College in South India. J Fam Community Med. 2016:23:88-93.

19. Lienhardt C, Fielding K, Silah J, Bah B, Gustafson B, Warndroff D, Palayew M, Lisse I, Donkor S, Diallo S, Manneh K, Adgbola R, Aaby P, Bah-sow O, Bennett S, McAdam K. Investigation of the risk factors for tuberculosis: a case-control study in three countries in West Africa. Int J Epidemiol. 2005; 34:914-9235.
20. Mitku A, Dessie ZJ, Muluneh E, Workie D. Prevalence and associated factors of TB/HIV co-infection among HIV infected patients in Amhara region, Ethiopia. Afr Health Sci. 2016;16(2):588-95.

21. Hill P, Jackon-Sillah D, Donkor S, Out J, Adegbola R, Lienhardt C. Risk factors for pulmonary tuberculosis: a clinic-based case control study in The Gambia. BMC Public Health. 2006:6(1):156.

22. Khazaei S, Molaeipoor L, Rezaeian S, Ayubi E, Yari M, Vallipour A, Khazaei S. Predictors of tuberculosis in HIV/AIDS patients referred to behavioral diseases consultation center:a registry-based study in Abadan, Southwest of Iran. Shiraz E Med J. 2016;17(10):e41542

23. Jurcev-Savicevic A, Mulic R, Ban B, Kozul K, Bacun-Ivcek L, Valic J, PopijacCesar G, Marinovec-Dunatov S, Gotovac M, Simunovic A. Risk factors for pulmonary tuberculosis in Croatia: a matched case-control study. BMC Public Health. 2013;13:991.

24. Taha M, Deribew A, Tessema F, Assegid S, Duchateau Land Colebunders R. Risk factors of active tuberculosis in people living with HIV/AIDS in Southwest Ethiopia: a case-control study. Ethiop J Health Sci. 2011;21(2): 131-40.

25. Komati S, Shaw P, Stubbs N, Mathibedi M, Malan N, Sangweni P, Metcalf J, Masur Hand Hassim H. Tuberculosis risk factors and mortality for HIV infected persons receiving antiretroviral therapy in South Africa. AIDS (London, England). 2010;24(12):1849.

26. Mohammed S, Tesfaye T. Tuberculosis among HIV-positive patients at Butajira Hospital, South-Central Ethiopia. Int J Pharma Sci Res. 2015;6(12): 1406-11.

27. Melkamu H, Seyoum B, Dessie Y. Determinants of tuberculosis infection among adult HIV positives attending clinical care in western Ethiopia: a case-control study. AIDS Res Treat. 2013;2013.

28. Hermans M, Kiragga A, Schaefer P, Kabugu A, Hoepelman A, Manabe Y. Incident tuberculosis during antiretroviral therapy contributes to suboptimal immune reconstitution in a large urban HIV clinic in Sub-Saharan Africa. PLoS One. 2010;5(5):e10527.

29. Agbaji O, Ebonyi AO, Meloni ST, Anejo-Okopi JA, Akanbi MO, Aguche S, Agaba PA, Sagay AS, Okonkwo P, Kanki P. Factors associated with pulmonary tuberculosis-HIV co-infection in treatment-naive adults in Jos, North Central Nigeria. J AIDS Clin Res. 2013;4:222.

30. LIU E, Makubi A, Drain P, Sepiegelman D, Sando D, Li N, Chalamilla G, Sudfeld C, Hertzmark E, Fawzi W. Tuberculosis incidence rate and risk factors among HIV-infected adults with access to antiretroviral therapy in Tanzania. AIDS. 2015;29(11):1391-9.

31. Awadalla H, Sammoni F, Soghaier M, Makki M. Risk factors associated with the development of tuberculosis among HIV-infected patients in Khartoum in 2010. AIMS Public Health. 2015;2(4):784

32. Mekonnen D, Derbie A, Desalegn E. TB/HIV co-infections and associated factors among patients on directly observed treatment short course in northeastern Ethiopia: a 4 years retrospective study. BMC Res Notes. 2015; $8(1): 666$

33. Belay A, Alamerew Z, Berie Y, Tegegne B, Tiruneh G, Feleke A. Magnitude and correlates of tuberculosis among HIV patients at Felege Hiwot Referral Hospital, Bahir Dar City, Northwest Ethiopia. Clin Med Res. 2013;2(4):77-83.

34. Fekadu S, Teshome W, Alemu G. Prevalence and determinants of tuberculosis among HIV infected patients in South Ethiopia. J Infect Dev Ctries. 2015;9(08):898-904

35. Molaeipoor L, Poorolajar J, Mohraz M, Esmailnasab N. Predictors of tuberculosis and human immunodeficiency virus co-infection: a case-control study. Epidemiol Health. 2014;36(6):e2014024.

36. Herrera Rodriguez FA, Agbo SO. An assessment of the risk factors for pulmonary tuberculosis among adult patients suffering from human immunodeficiency virus attending the Wellness Clinic at Themba Hospital. S Afr Fam Pract. 2015;52(2):106-11.

37. Alvi A, Rizawan M, Sunosi $R$, Jerah $A$. Does khat-chewing increases the risk of mycobacterium tuberculosis infection by macrophage immune modulation? Med Hypotheses. 2014;82(6):667-9.

38. Esmael A, Tsegaye $\mathrm{G}$, Wubie M, Endris M. Tuberculosis and human immune deficiency virus co-infection in Debre Markos Referral Hospital in Northwest Ethiopia: a five years retrospective study. J AIDS Clin Res. 2013:4:263.

\section{Publisher's Note}

Springer Nature remains neutral with regard to jurisdictional claims in published maps and institutional affiliations. 